\title{
水熱ホットプレス法によるコンクリート廃材の固化体合成技術の開発と 評価に関する研究
}

\author{
中根裕司・佐藤一志・高橋秀明・山崎仲道*・橋田俊之 \\ 東北大学工学部附属破壞力学応用研究施設, 980 仙台市青葉区荒巻字青葉 \\ *高知大学理学部附属水熱化学実験所, 780 高知市曙町 2-5-1
}

\section{Development of Solidification Technique for Recycle of Concrete Wastes by Hydrothermal Hot-Pressing and Its Mechanical Property}

\begin{abstract}
Yuji NAKANE, Kazushi SATO, Hideaki TAKAHASHI, Nakamichi YAMASAKI* and Toshiyuki HASHIDA
Research Institute for Fracture Technology, Faculty of Engineering, Tohoku University, Aoba, Aramaki, Aoba-ku, Sendai-shi 980

*Research Laboratory of Hydrothermal Chemistry, Faculty of Science, Kochi University, 2-5-1, Akebono-cho, Kochi-shi 780
\end{abstract}

[Received November 15, 1993; Accepted January 27, 1994]

\begin{abstract}
A new processing method for solidifying pulverized concrete wastes is presented. The objective of this study was to develop a technology to recycle concrete wastes. Concrete wastes were pulverized and then solidified by a hydrothermal hot-pressing method, which is a press-forming technique under hydrothermal conditions using an autoclave. The reaction temper" ature was in the range of 120 to $300^{\circ} \mathrm{C}$, and the reaction time was in the range of 10 to $40 \mathrm{~min}$. The tensile strength of the solidified concrete waste was determined by a Brazilian test. It was shown that concrete waste can be solidified under the above reaction conditions. The measured tensile strength increased with increasing temperature, and a steep increase was observed at the reaction temperatures of 150 to $200^{\circ} \mathrm{C}$. The tensile strength of $5 \mathrm{MPa}$ was achieved above $200^{\circ} \mathrm{C}$. The steep increase in the tensile strength was shown to be due to the formation of tobermorite.
\end{abstract}

Key-words : Hydrothermal hot-pressing, Concrete wastes, Reuse, Solidification, Strength, Tobermorite

\section{1. 緒言}

近年, コンクリート構造物の老朽化などに伴う取り壊し により，コンクリート廃材が量的に増大する傾向にある。

これまでは，埋め立てに用いるなどして処分されてきた が，都市周辺の環境の変化により適当な地域に処分地を得 ることが困難になっている。一方, コンクリート廃材を粉 研し、コンクリートの粗骨材として再利用する場合もあ る。以上の状況を踏屯えると, コンクリート廃材を資源と して積極的に再利用する技術の開発は, 省資源の観点から も大変有意義なことと予想される1). 本研究では, 水熱 ホットプレス法によりコンクリート廃材の固化合成を試 み, 新しい再利用技術の開発を目指す。水熱ホットプレス 法2)は，水を含む無機化合物粉末を水熱条件下で加圧する ことにより粒子間隙に存在する水を搾り出すと同時に粒子 を連結し，機械的強度の高い緸密化した固化体を作製する 方法である。この固化反応は通常の焼結反応に類似してい
るが，適量の水の介在下で溶解一析出や新たな結晶物質の 生成などが起こる。この新しい固化方法を用いて, コンク リートの廃棄物の固化を検討し, 生成した固化体の観察及 び㙨械的特性の評価を行う。

\section{2. 実験装置}

実験に使用した水熱ホットプレス用オートクレーブの断 面図を図 1 に示す。オートクレーブ本体は，内径 $30 \mathrm{~mm}$ のピストンシリンダー型構造である。シリンダー内部に蒸 留水を混ぜた試料を充填した後，上下方向からピストンに 圧力を加えることにより試料を一軸加厈することができ る、なた，ピストンには，試料から搾り出された高圧蒸気 のための逃げ空間があり，この空間によって試料中の水分 が調節される．更に，ピストンと押し棒の間には，テフロ ン製グランドパッキングがあり，上下方向からの厈力によ り変形して固化反応中の試料を水熱状態に保つことができ る. 試料への加圧は，インストロン万能試験機を用い, オートクレーブの加熱はシース型ヒーターで行った。 その 昇温速度は約 $9^{\circ} \mathrm{C} / \mathrm{min}$ とした。

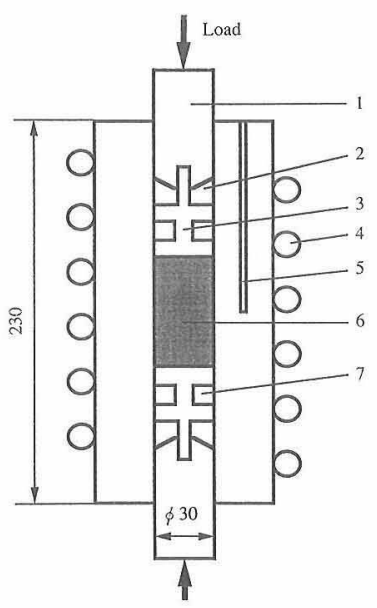

Fig. 1. Autoclave for hydrothermal hot-pressing. 1 : Push rod, 2 : Gland packing, 3 : Cast rod, $4:$ Heater, 5 : Thermocouple, $6:$ Sample, $7:$ Space for water retreat. 


\section{3. 供試材及び実験方法}

本実験に供した材料は, コンクリート工場に約 1 年間 放置されていたコンクリート廃材を，骨材が混入している 状態のまむボールミルにより平均粒度 $35 \mu \mathrm{m}$ に粉砕した ものを用いた。蛍光 X 線による定量分析結果を表 1 に示 す。出発材料は,このコンクリート廃材に蒸留水を混ぜた ものを用いる，固化体の合成条件は，上下方向からピスト ンに加える圧力を $20 \mathrm{MPa}$ ，コンクリート廃材に加える水 分量を $10 \mathrm{wt} \%$ とし，反応温度 $120 \sim 300^{\circ} \mathrm{C} て ゙ ，$ 所定の反応 温度に達してから10〜40分間保持した，得られた円盤状 固化体をエメリ一紙\#600にて研磨したのち圧裂試験了を行 い, 求めた破断荷重（最大荷重）を次式に代入して引張り 強度 $\sigma_{\mathrm{f}}$ 孝算出した。

$$
\sigma_{\mathrm{f}}=2 P_{\max } / \pi d t
$$

ここで, $P_{\max }$ は最大荷重, $d(=30 \mathrm{~mm})$ は試験片直径, $t$ は試験片板厚， $\pi$ は円周率である。

比較のため, 前述のコンクリート廃材と同一の骨材を粉 砕し，セメントと混合して作製したモルタルを水中養生し た後，同様の強度評価を実施した。ここで，水一セメント 比は30 wt\%であり，養生時間は28日である。

更に, 圧裂試験後の固化体の破面を走査型電子瀕微鏡 （SEM）により観察した.

\section{4. 結果及び考察}

比較的低温かつ短時間の条件で，水熱ホットプレス法に よりコンクリート廃材の固化体が得られることを見いだし た，図 2 に，固化体合成時の反応温度と，圧裂試験の結果 より評価された引張り強度の関係を示す，比較のため試験 した水中養生モルタルの引張り強度は0.26 $\mathrm{MPa}$ でめり, 図中に破線で示してある。この值は, 通常のモルタルに経 験される強度值と同等の值を与えている. 水熱ホットプレ 不法で得られた廃材の固化体の方が，水中養生モルタルの 引張り強度に比べ高い值を示している. 固化体の引張り強 度は，反応温度の上昇に伴い，増加の傾向にある。 反応時 間10〜30分では反応温度 $180 \sim 200^{\circ} \mathrm{C}$ の間，反応時間 40 分 では反応温度 $150 \sim 180^{\circ} \mathrm{C}$ の間で引張り強度が急増してい ることが分かる。

図 3 に, 圧裂試験後の固化体の破面の SEM 写真を示 す。これらの合成条件は，反応時間 20 分，圧力 $20 \mathrm{MPa}$, 水分量 $10 \mathrm{wt} \%$ で，反応温度がそれぞれ150，180，200， $250^{\circ} \mathrm{C}$ に㧈いて得られたものである。 反応温度 $180^{\circ} \mathrm{C} の$ 写 真 (b) では，反応温度 $150^{\circ} \mathrm{C}$ の場合に見られない針状の結

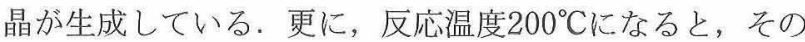

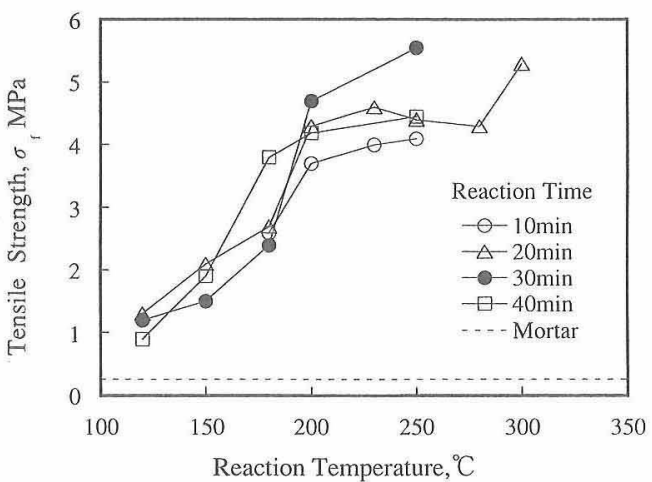

Fig. 2. Relation of tensile strength vs reaction temperature. The tensile strength increases rapidly at the reaction temperatures of $150-200^{\circ} \mathrm{C}$.

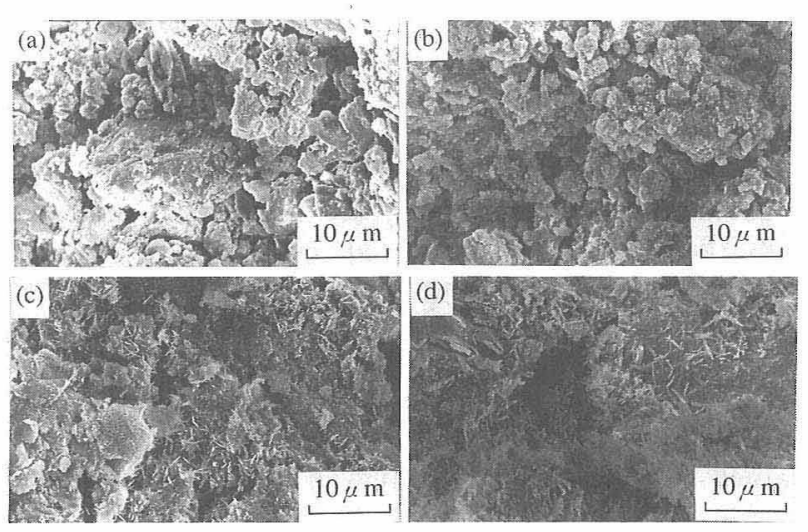

Fig. 3. SEM observation of fracture surfaces. Reaction temperatures are: (a) $150^{\circ} \mathrm{C}$, (b) $180^{\circ} \mathrm{C}$, (c) $200^{\circ} \mathrm{C}$, (d) $250^{\circ} \mathrm{C}$.

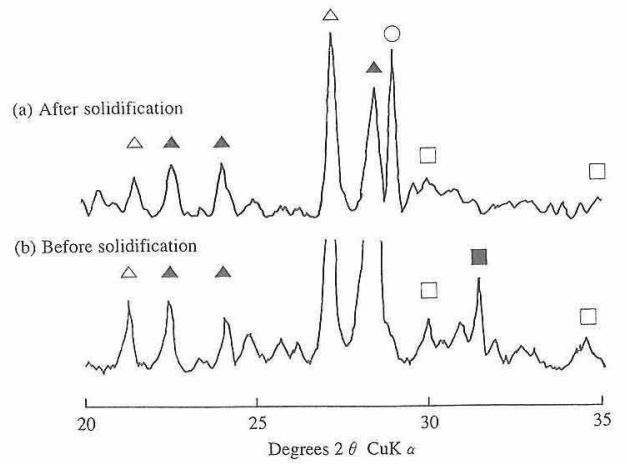

Fig. 4. X-ray diffraction profiles.

(a) After solidification, (b) Before solidification.

Tobermorite $\left(2 \theta=28.9^{\circ}\right)$ appeares after solidification ( $\left.\bigcirc\right)$, Quartz $(\triangle)$, Feldspar $(\triangle), \mathrm{Ca}(\mathrm{OH})_{2}(\square), \mathrm{CaO}(\square)$.

Table 1. X-Ray Fluorescence Analysis Value

\begin{tabular}{|c|c|c|c|c|c|c|c|c|c|c|c|c|}
\hline Material Element & $\mathrm{SiO}_{2}$ & $\mathrm{Al}_{2} \mathrm{O}_{3}$ & $\mathrm{TiO}_{2}$ & $\mathrm{Fe}_{2} \mathrm{O}_{3}$ & $\mathrm{CaO}$ & $\mathrm{MgO}$ & $\mathrm{Na}_{2} \mathrm{O}$ & $\mathrm{K}_{2} \mathrm{O}$ & $\mathrm{SO}_{3}$ & $\mathrm{P}_{2} \mathrm{O}_{5}$ & $\mathrm{MnO}$ & Balance \\
\hline Fresh Concrete & 50.92 & 13.36 & 0.87 & 7.86 & 12.91 & 4.36 & 1.38 & 1.21 & 1.77 & 0.14 & 0.15 & 2.43 \\
\hline Concrete Waste & 50.64 & 12.49 & 0.76 & 7.29 & 11.60 & 3.58 & 1.48 & 1.29 & 1.77 & 0.10 & 0.12 & 7.59 \\
\hline
\end{tabular}


結晶は板状に成長し, 反応温度 $250^{\circ} \mathrm{C}$ では数 $\mu \mathrm{m}$ の大きさ の結晶が群生していた．このように反応温度の上昇により 成長する結晶が，固化体の引張り強度に影響を及ぼしてい るものと考えられる.この結晶を分析するために, 反応温 度 $200^{\circ} \mathrm{C}$ で合成した固化体の粉末 $\mathrm{X}$ 線回折図形を図 4 に示 す. 固化前の廃材には見られないトバモライトに対応する $2 \theta=28.9^{\circ}$ の回折ピークが水熱ホットプレス法で固化合成 した後の固化体では現れている. 表 1 に示した $\mathrm{SiO}_{2}$ は, コンクリート中の骨材として多く存在するが，本実験で試 料として用いたコンクリート廃材は骨材も含め粉砕されて いるため, $\mathrm{SiO}_{2}$ は微粒子で存在し, その表面は再び反応 性に富むものとなる. そのため, 固化合成反応は $\mathrm{SiO}_{2}$ 過 多の条件下で進み, その結果, トバモライトが生成する可 能性が大きいと考えられる4),5). トバモライトは，オート クレーブ処理に打いて, 通常 $180^{\circ} \mathrm{C}$ 前後で, $4 \sim 16$ 時間養 生することにより, 安定に析出することが知られてい る5),6). しかしながら, 本実験の水熱ホットプレス法では 数十分程度の処理でトバモライトが析出したという事実 は，水熱ホットプレス法が，水熱反応のみならず機械的圧 搾の効果を同時に利用しているためと判断される。このト バモライトの析出による機械的強度の増加はすでに知られ ており6),7), 図 2 で観察された引張り強度の不連続な上昇 は, トバモライトの析出とその成長によるものと考えられ る.

一般には，コンクリート廃材の状態は経年変化や，用途 の違いによる成分が種々異なる場合が多いが，それらのコ ンクリート廃材も本実験で用いたものと同様に粉砕し, 新 たな活性な面を出すことで, 水熱ホットプレス法の反応過
程に抢ける機械的圧搾と水熱反応により，再び物質の移 動，変質，析出がおこり，高強度の固化体を合成できるも のと考える.

\section{5. 結 言}

（1）水熱ホットプレス法を用いることにより，比較的 低温かつ短時間の条件 $\left(120 \sim 250^{\circ} \mathrm{C}\right.$ で数十分）でコンク リート廃材の固化体を合成できることを見いだした。 その 引張り強度の範囲は, 1〜 $5 \mathrm{MPa}$ であった。

(2) $200^{\circ} \mathrm{C}$ 上の合成温度では，トバモライトの析 出, 成長により, 引張り強度 $5 \mathrm{MPa}$ 程度の高強度固化体 を合成できる。

謝辞本研究を遂行するに当たり, 有益な討論を頂戴し た, 高知大学理学部附属水熱化学実験所の西岡 守技官に深く感 謝申し上げる。 また，前田製管株式会社には，廃コンクリート材 料の提供をして頂いた。ここに記して感謝申し上げる.

\section{文献}

1) 西岡守，山崎仲道，ウェイストリソース，24, 7-11 (1991).

2）山崎仲道，柳沢和道，西岡 守，ニューセラミックス，10, 81-86 (1989).

3）例えば, 丹羽義次監修, “岩石力学入門”, 東京大学出版会 (1977) p. 124.

4）光田 武，セメント技術年報，41, 9-17 (1987).

5）光田 武，セメント技術年報，30, 45-49 (1976).

6）鈴木一孝, 浅川邦治, 土田幸宏, 伊藤祐敏, 福尾券一, 羔協, 85, 440-47 (1977).

7）井須紀文，寺村敏史，佐々木 香，石田秀輝，光田 武，日 本セラミックス協会年会講演予稿集 (1993) pp. 504-05. 